\title{
Understanding the Level of Students' Reading Comprehension Ability
}

\author{
Meilani Harfika Sari ${ }^{1}$, Susetyo ${ }^{1}$, Noermanzah ${ }^{1, *}$, Dian Eka Chandra Wardhana ${ }^{1}$, \\ Dewi Kusumaningsih ${ }^{2}$ \\ ${ }^{1}$ Department of Language and Arts Education, University of Bengkulu, Indonesia \\ ${ }^{2}$ Department of Language and Arts Education, Veteran Bangun Nusantara University, Indonesia
}

Received March 21, 2020; Revised April 12, 2020; Accepted April 27, 2020

Copyright $\odot 2020$ by authors, all rights reserved. Authors agree that this article remains permanently open access under the terms of the Creative Commons Attribution License 4.0 International License

\begin{abstract}
Reading comprehension of texts is a basic competency in the Indonesian Subject Curriculum. The observation results show that reading comprehension is still low, especially reading comprehension of the meaning of the text and the context of a text. From these problems, it is necessary to conduct research on the level of reading comprehension of grade VII students of SMP Negeri 06, Rejang Lebong. This research aimed at describing the level of reading comprehension ability and the causes of students' misunderstanding in grade VII of SMP Negeri 06 Rejang Lebong on reading text material. This research belongs to mixed method design. The subjects of this study were 28 students of class VII from SMP Negeri 06, Rejang Lebong. Data were collected using tests, observation, interviews, and documentation. Data were analyzed qualitatively and quantitatively. Data validity test is done by member checking, which is assisted by language validator and triangulation. The results showed that students were not accustomed to reading texts and there were still those who were not fluent in reading.
\end{abstract}

Keywords Skill Level, Reading Comprehension, Text Meaning and Context

\section{Introduction}

Reading is part of the education process, as explained by the Minister of Education [11] in Regulation of Minister Education Number 68 of 2013 concerning the Basic Framework and Curriculum Structure which states that the education is a process that gives students the opportunity to develop students' potential. The statement explained that reading is part of the educational process of developing self-potential. Reading is getting the meaning of what he reads [13]. Reading comprehension is an activity by reconstructing the reader's knowledge which directs the reader to critically interpret and analyze every part of the text so as to get an understanding of the actual reading content [6].

[19] explains that reading is a process carried out by the reader to get the message. [15];[17] state that reading is a complex activity that involves not only reciting writing, but also visual activity. [5] explains reading as a complicated activity and indicated that reading ability was a specific ability. Reading has something in common with talking in terms of processing information. In this case, reading also requires rules such as maxim of cooperation which requires initial knowledge of the topic to be discussed [18].

[22] argues that reading is digging up information from the text. According to Suyana (2019: 19), reading is an activity that exerts several actions including physical or cognitive actions. As a visual process, reading is the process of translating written symbols into spoken words. According to [14], reading is skill that everyone has different abilities.

Then, [16] revealed that reading comprehension is a complex intellectual process that includes two main abilities, mastery the meaning of words and to think about verbal concepts. According to [3], reading is an evaluation process of information. The reader must decide whether the information read is coherent and suitable for the purpose of reading. This evaluation also extends to the reader's motivation, reader's attitude to topic, reader's feelings of success, and reader's expectations from the text will be useful or interesting. According to [15] reading comprehension is a process of social constructivity that is building new word meanings based on prior knowledge. Based on some of opinions, it can be concluded that the ability to read is the ability obtained by students during the learning process. With students skilled in reading, they will carry out a production process that can produce new 
knowledge, experience and attitudes. Like a company that produces something through the process of reading, activities aim to process reading in order to obtain information. The reading comprehension is an interactive process between the text and the background knowledge of the previous reader [21].

According to [4], the purpose of reading comprehension is 1) to find simple information, 2) skim quickly, 3) takes place in academic and professional contexts, 4) integrate information, write and criticize texts. For reading comprehension assessment reading characterization provides, the national reading framework explains that reading comprehension is an active and complex process involving: a) understanding written texts, b) developing and interpreting meanings, and c) using meanings that fit the type of text, poses, and the situation [1]. Then, the factors that influence the ability to read comprehension according to [20] are physiological, intellectual, environmental, socio-economic, and psychological factors.

Based on the results of preliminary observations, it shows that the ability of students of SMP Negeri 06 Rejang Lebong in reading comprehension is still lacking. Students are still unable to spell words and determine global information, selective information, and detailed information contained in the discourse and interpret the vocabulary in the sentence, even though they have experienced the learning process by using the maximum time allocation. This is what makes us interested in researching about the level of reading comprehension of junior high school students to explain at what position the level of reading comprehension ability of students so that the best solution can be overcome.

Research on reading ability has been done by [2] about the problem of comprehension of reading texts in Indonesian Language class IV MI Ianatusshibyan Semarang students in the academic year 2015/2016. There are still many students who read less attention to punctuation, do not recognize the meaning of words, that reading speed is less flexible, can not develop visual imagination, can not recognize the organization of essays, and could not find the main idea in the reading. The results of this study indicate that the ability to understand reading texts is still below average. The second study is [20] about the ability to read comprehension of grade VII students of SMP Negeri 1 Kerkap based on Barret's Taxonomy in the academic year 2013/2014. The results of the study showed that students' reading ability was still low. The third study [8] examined the ability to read comprehension based on Barret's Taxonomy in fourth grade students of SD Negeri Gugus Dwija Harapan, Mijen. The results of this study indicate that the average reading comprehension of Grade IV students at SD Negeri Gugus Dwija Harapan is in the sufficient category. Even though it is in the sufficient category, the average results of the reading test in the understanding of students of SD Negeri Gugus Dwija Harapan are still below the specified minimum criteria. The average value obtained is 6.6 while the minimum value specified is 75 .

The three relevant studies above have relevance to this research, both examining students' reading comprehension abilities. In the three studies, the research was only limited to the problematics and reading comprehension ability of students. While this study is not only limited to the reading comprehension problem at Rejang Lebong 06 State Junior High School, but the researcher is trying to find the level of reading comprehension ability and the causes of students' understanding in reading texts, then the reading comprehension level using HOTS-based questions.

From some of the relevant research above, it shows that the level of reading comprehension ability in SMP Negeri 06 Rejang Lebong has not been studied. The benefits of this research are expected to be able to add insight and develop knowledge about the problem of reading comprehension issues. In addition, it can be used as input for Indonesian language teachers in improving students' reading comprehension skills.

\section{Materials and Methods}

The research was mixed method. This mixed method is used to better understand the research problem by converging quantitative data in the form of numbers and qualitative data in the form of descriptive details. The subjects of this study were 28 students of class VII from SMP Negeri 06, Rejang Lebong. Data were collected using test, observation, interviews, and documentation. The reading comprehension test instrument is in the form of 25 multiple choice tests that represent the ability to understand written texts, develop and interpret meanings, and use meanings appropriate to the text, poses, and situations. Observation and interview techniques were carried out to see the reading culture of students' understanding at school and home. Data analysis techniques in this study refer to the mixed method of analyzing qualitative and quantitative. Analyzing qualitative data were from observation, interview, and documentation while analyzing quantitative data were from test result. After getting qualitative and quantitative data, it then proceeds to give the meaning and conclusions. Data validity test is done by checking and triangulating. Checking is done by tabulating data, interpreting data by researchers and language validators while triangulation obtained from tests of reading comprehension skills, observations, interviews, and documentation.

\section{Results and Discussion}

\subsection{Results}

The level of reading comprehension of grade VII students of SMP Negeri 06 Rejang Lebong is still relatively low, indicated by the results of reading 
comprehension test, observations, and interviews. The research results are as follows:

\subsubsection{Level of Reading Comprehension Ability}

The following will present the results of the research on reading comprehension that has been conducted by researchers for 3 months starting from December 2019 until February 2020.

\section{a. Reading Comprehension Ability Test Results}

The test used in this study is a multiple choice comprehension reading ability test. This multiple choice comprehension reading test consists of 25 questions based on HOTS. Multiple choice questions with 4 answer choices done within 60 minutes. After collecting data the data is obtained as follows.

Table 1. Results of Reading Ability Ability Test Results for Class VII Students of SMP Negeri 06 Rejang Lebong

\begin{tabular}{|c|c|c|c|c|}
\hline Number & $\begin{array}{c}\text { Type of } \\
\text { Questions }\end{array}$ & $\begin{array}{l}\text { Number of } \\
\text { Questions }\end{array}$ & $\begin{array}{l}\text { Average } \\
\text { Value }\end{array}$ & Criteria \\
\hline 1. & $\begin{array}{l}\text { Understand } \\
\text { written text }\end{array}$ & 10 & 9 & Less \\
\hline 2. & $\begin{array}{c}\text { Develop and } \\
\text { interpret meanings }\end{array}$ & 9 & 9 & Less \\
\hline 3. & $\begin{array}{l}\text { Use contextual } \\
\text { meaning }\end{array}$ & 6 & 7 & Less \\
\hline \multicolumn{2}{|r|}{ Amount } & 25 & 25 & Less \\
\hline
\end{tabular}

From the table above, it can be explained that the reading comprehension of grade VII students of SMP Negeri 06 shows that the average value of 25 out of a maximum score of 100 is included in the criteria of lack. In the reading comprehension test, the type of questions consists of three question indicators. In the first indicator, there are 10 questions that discuss the understanding of the written text, each question has a weight of 4 . After doing the recapitulation, an average value of 9 from the maximum value of 40 is obtained. The average results fall into the criteria of lacking.

In the second indicator, there are 9 questions that discuss developing and interpreting meaning. From the overall recapitulation results, it obtained an average value of 9 out of a maximum value of 36 which if entered into the criteria table get less criteria. Likewise in the third indicator, there are 6 questions that discuss about using meaning contextually. From the recapitulation results, it obtained an average value of 7 from a maximum value of 24. This indicator also falls into the under criteria. Develop and interpret meanings. From the overall recapitulation results, it obtained an average value of 9 out of a maximum value of 36 which if entered into the criteria table get less criteria. Then, the results of the percentage of reading comprehension tests can be shown in the following table.

Table 2. Percentage of Individual Value of Reading Comprehension Tests

\begin{tabular}{|c|c|c|c|c|}
\hline Number & Score & $\begin{array}{c}\text { Total } \\
\text { Students }\end{array}$ & Percentage & Criteria \\
\hline 1. & $23-44$ & 20 & $71 \%$ & Less \\
\hline 2. & $1-22$ & 8 & $29 \%$ & Very less \\
\hline
\end{tabular}

The value of each individual obtained the highest value of 44 with less criteria. The number of subjects studied was 28 students, out of a total of 28 students, 20 students received grades between 23 - 44 with less criteria and 8 students entered into very poor criteria that scored between 1-22. If it is made in the form of a percentage, a percentage of $71 \%$ is obtained for students whose reading comprehension is still lacking and the remaining $29 \%$ falls into the very poor criteria.

The percentage of reading comprehension test results can also be seen in the form of a chart as below.

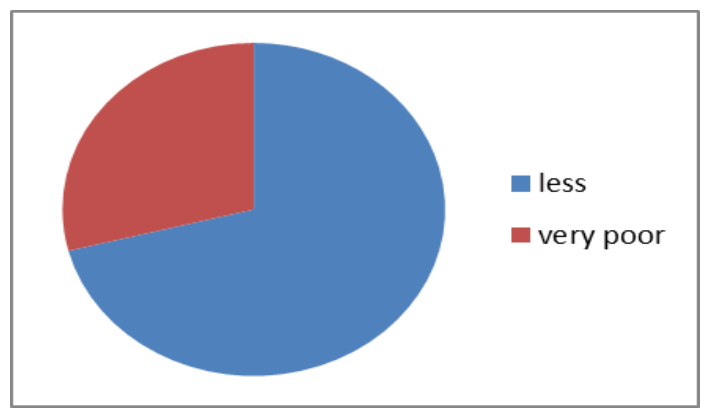

Figure 1. Percentage of Individual Values in Reading Comprehension of Grade VII Students at SMP Negeri 06 Rejang Lebong

\section{b. Results of Reading Comprehension Habits}

The results of reading comprehension habit are obtained from observation data or direct observations of students for 3 months from December 2019 to February 2020. Observations are made by observers in the form of observations of students' activities in the school environment and also in the home environment, so that data are obtained about the reading activities of students at school or at home. The results of the observation can be seen as follows: 
Table 3. Recapitulation of Research Results Reading Comprehension of Class VII Students of SMP Negeri 06 Rejang Lebong

\begin{tabular}{|c|l|l|}
\hline Number & $\begin{array}{l}\text { Aspects Observed in Reading } \\
\text { Activities Understanding }\end{array}$ & \multicolumn{1}{c|}{ Information } \\
\hline 1. & $\begin{array}{l}\text { Understanding the literal } \\
\text { meaning }\end{array}$ & $\begin{array}{l}\text { Understanding of the contents of the text read is still lacking. Students tend to forget } \\
\text { the contents of the reading material they have read. Students find it difficult to explain } \\
\text { meaning back literally, such as difficulty to explain the conclusion of the text, the title } \\
\text { of the text, and the meaning of the word it reads }\end{array}$ \\
\hline 2. & Understanding non-literal & $\begin{array}{l}\text { Non-literal understanding of children is still lacking. children are still very difficult to } \\
\text { interpret text in abstract terms. Children have difficulty when explaining the meaning } \\
\text { of figurative words in a poem. }\end{array}$ \\
\hline 3. & $\begin{array}{l}\text { The habit of reading in the } \\
\text { library }\end{array}$ & $\begin{array}{l}\text { Students read in the library only when given instructions by the teacher to the library. } \\
\text { Students do not have their own awareness to read in the library. }\end{array}$ \\
\hline 5. & The habit of reading in class & $\begin{array}{l}\text { Activities reading in class is done when teaching and learning activities only. If not in } \\
\text { learning activities students spend time playing with friends. }\end{array}$ \\
\hline 6. & Reading habits at home & $\begin{array}{l}\text { Reading activities at home are still lacking. Students do not have reading material } \\
\text { facilities from parents. The reading material students have is only textbooks obtained } \\
\text { from school and will only read the book when there is homework from school. And } \\
\text { parental control is absent. }\end{array}$ \\
\hline Reading fluency & $\begin{array}{l}\text { For reading fluency is still lacking. This can be seen from when students read children } \\
\text { often repeat the words they read, do not follow the intonation of reading, pausing long } \\
\text { on words that are affixed. And while reading students still use the tip of the index } \\
\text { finger to read the words in the text of the reading material. }\end{array}$ \\
\hline
\end{tabular}

From the table above, it can be explained as follows, understanding literal and non-literal meaning according to the results of observations that have been made both directly to observe children's learning activities, the observer also provides a series of reading comprehension tests to students to obtain more valid data by providing material reads in the form of short texts of literature and non-literature. From the reading material students have read, the observer gives a number of questions about the literal and non-literal meaning related to the reading material. From a series of observations and tests, it was found that understanding of the literal meanings and nonliteral meanings of students is still lacking. Students still have difficulty explaining and understanding the meaning of the literal and non-literal words in the text of the reading material.

Difficulties in explaining and understanding meaning literally and non-literally can be caused by the lack of discipline of students to read. Students are still very rarely to read in the school library in their own awareness. They will go to the library if there are teaching and learning activities that require them to go to the school library. Then, the teacher still lacked time for students to read in the library. Reading activities in the library are only carried out by Indonesian Subject teachers. For other subject teachers it is still very rare to read in the library.

Likewise, the habit of reading in class is only when teaching and learning activities take place. Reading activities in class are done if given the task to read by the teacher. Awareness to read on the basis of self-awareness is still lacking. Most of these students have objections to reading books although indirectly in daily life without them knowing they are doing reading activities. The progress of the digital world seems to force them to abandon reading activities, they are more interested in reading articles on the internet, comics, story books, reading messages through message sharing applications, and social media.

Discipline of time to read is not done at home. They will read textbooks if there are homework assignments from school. Parents of students who on average work as Farmers, Traders, Civil Servants, and Private are still lacking in facilitating reading material at home. Supervision of children's learning hours at home is still very lacking. Parents are too busy working so that they pay less attention to their children in terms of supervision at home during the day. At night even children are not accustomed to learning.

Children's activities after school are spent playing with friends and playing games. The role of supervision that should be done by parents is still lacking, resulting in these children not doing routine reading at home. Then, the parents do not provide interesting reading material at home. This results in a lack of interest in children's reading.

\subsubsection{Causes of Ignorance of Text Material Readings}

The cause of students' lack of understanding of the reading material was obtained from interviews with 28 students who had difficulty reading comprehension. From the results of in-depth interviews, it found with several causes of students not understanding the text of the reading material, as follows.

\section{a. Reading Hobby}

Of the 28 students interviewed, 20 said they had a hobby of reading and 8 said they did not like to read. The reading material they read is reading comics, articles on the internet, Facebook, various messaging applications and other social media. They find reading via a mobile phone more interesting than reading textbooks and reading what they consider to be a tedious activity that is 
textbooks.

Textbook reading activities that are still lacking make students not accustomed to reading standard words. Students' interest in reading on social media and reading messages through a message sharing application can cause children not accustomed to reading or understanding standard words. This can occur because the language used on social media and messages through a message sharing application are non-formal words, which results in students' lacking formal vocabulary.

When reading text, children have difficulty reading and understanding absorption words, words that have experienced affixation, and words that combine two consonant letters in one word. When looking at the text of a long reading material, the students consider it to be very difficult to find the meaning contained in the text. Lack of students' understanding of words that come from absorbed languages, affixed words and a combination of consonant letters can be due to the lack of interest in students' reading books.

\section{b. Reading Activities}

The cause of students' lack of understanding of the text of reading material can be caused by reading activities that are still lacking, both at school and at home. Reading activities at school are only carried out when teaching and learning activities take place. During free time or school breaks, students used to go to the canteen and play with friends. The library which is a storehouse of knowledge is not utilized properly. Students will only go to the library if there is instruction from the teacher to carry out reading activities in the library. Students still do not have their own awareness to read independently in the library.

The free time available after school is not used for reading, activities at home are used for playing with friends, playing online games and watching television. Book reading activities will be carried out if there are school assignments given by the teacher. Supervision from parents when at home is still lacking, parents do not provide adequate facilities for children to read at home. This is evidenced by the recognition of students who do not have their own space to study and there are no interesting reading material books at home. Parents also do not provide books that are interesting reading material at home. Children's reading books are only textbooks originating from school, so it makes students less interested in reading textbooks at home because they find reading textbooks boring and will be read if forced to.

\section{c. Difficulties in Understanding Reading}

The cause of students' lack of understanding of reading material is also caused by students' difficulty in understanding reading. Difficulties of students in reading words that are affixed, words of absorption, and the combination of consonant letters in one word result in difficulty students understand reading.
Students have difficulty in working on the test questions given. This can be seen from the reading test results of understanding that is still lacking. The difficulty of students is not only in doing test questions, but students have difficulty in explaining and concluding the contents of the text they are reading.

\section{d. Smooth Reading}

One of the factors that most influences students' understanding of the text of reading material is the smooth reading. Students are still not fluent in reading. Unevenness in reading can be seen as follows.

1. Difficult reading words that have affixes, when reading words that have affixes most students have difficulty and sometimes change the words they read.

2. Difficult to read words that come from the absorption language, when reading words that have absorption words students halt spelling per letter they read.

3. Do not understand punctuation, most students do not pay attention to punctuation, resulting in intonation that is less precise.

4. Repeating words that are read, when finding words that are long and difficult to read students will repeat the words read.

5. Stop long on long words, almost the same as the previous point students will also stop long when finding words that are difficult to read as if spelling out in the heart.

6. Still using the tip of the index finger to point to the word being read, students still use the tip of the index finger to point to the word they are reading and if not using the tip of the index finger the student has difficulty reading the next line of sentences.

\subsection{Discussion}

Grade VII students of SMP Negeri 06 Rejang Lebong have problems reading comprehension. This is indicated by the low level of reading comprehension ability which is only limited to the understanding of the level of understanding the meaning of the written text. Though what is expected in reading students' understanding must be able to not only understand written meaning, but be able to develop and interpret meanings and use meanings that are appropriate to the type of text, poses, and situations [1]. Three aspects of the assessment aspect get an overall average value of 25 from a maximum value of 100 , which consists of understanding aspects of written text with an average value of 9 out of a maximum value of 40. Aspects of developing and interpreting meanings are with an average value of 9 from the maximum value of 36 and finally aspects using the contextual meaning with a value of 7 from the maximum value of 24 . All three aspects fall into the under criteria.

To determine the ability to read students' understanding 
of the text of the reading material, the researcher also observed the reading activity. Among them observing the ability of children to understand meaning literally and nonliterally. From the observation results, it is known that students still do not understand the literal and non-literal meaning well. Students still have difficulty explaining the contents of the text they are reading. In fact, understanding texts literally is a basic skill in reading comprehension.

This opinion is reinforced by [14] the level of children's reading ability can also be seen from the ability of children to understand the meaning that exists in the text of reading material that is the literal and non-literal meaning. The literal reading level is the lowest reading level because literal reading only recognizes and captures written material that is written explicitly.

From this opinion, it can be concluded that literal reading is the easiest reading stage to do because it only captures the meaning explicitly, as written by the author. Lack of students' understanding of the text of reading material can be caused by reading activities of students who are still lacking in discipline. Students only read on teaching and learning activities in schools. Free time at school is used for eating and playing with friends. Students do not have their own awareness to read in the school library. This lack of time discipline for reading causes students to experience problems in reading comprehension.

This agrees with what was stated by [15] who argues that constructivists believe that students build knowledge by connecting knowledge with knowledge that they already know. In reading, this concept is reflected in the development of learning based on the scheme, which believes that learning occurs when new information is integrated with what is known [6]. For a student who has more experience in a particular topic, it is easier to make connections between what he knows and what he will learn so that he has good communication skills [9].

From these statements,it can be seen that reading comprehension is a long process that requires students' reading experience. To understand the reading material of a reading material, students must have a lot of previous reading experience, so that the more students read, the more information they will get, making it easier for students to understand the text of the reading material to be read.

To overcome the problem of reading comprehension, it should be started from the application of the method used by the teacher when reading activities that can be done with the SQ3R method. This method has been proven by $[10]$ as a solution that can be used by teachers so that there are no boring factors in language learning, especially reading. Reading comprehension by applying the SQ3R method and giving rewards will be more effective than other reading comprehension methods, this method requires students to explore their understanding with the five stages of the reading process consisting of surveying content, making questions, reading content, telling content, and reviewing the reading that will be combined with giving rewards to students who can complete the task well. Then the learning process will take place very interesting.

The SQ3R method is a systematic and practical learning procedure. The SQ3R method is an excellent reading method for the purpose of intensive and rational reading. [10] states about effective study, through reading activities using the SQ3R method (1) survey, which is to investigate first to get a glimpse of the contents to be studied; (2) question, which is asking questions from the main idea or the contents of a book that is read in passing; (3) read, i.e. read actively to provide answers to the questions made; (4) recite, i.e. repeating the answer given to the question by not looking at the book against the small notes that outline; and (5) review, i.e. repeating what it reads by checking the notes.

Then, to overcome the problem of the ability to read comprehension in grade VII students of SMP Negeri 06 in Rejang Lebong, according to [12], forming efficient reading habits requires a relatively long time. In addition to time, the factors of desire and will and motivation need to be present, but desire and will must be strengthened by motivation. In addition, environmental factors also play a role. If the environment does not encourage, and even inhibits, reading habits are difficult to obtain, or even will not be formed. Therefore, formation efforts should begin as early as possible in life, namely from childhood.

In childhood, the formation effort in the sense of laying the foundation of good interest can begin from around the age of two years, that is, after children begin to be able to use spoken language (understanding what is said and spoken). Some of the efforts that can be done are increasing the role of parents and early reading habits. The influence and role of parents can be done by encouraging the development of children's language, being an example in reading, reading and telling stories, playing with reading and writing [7], and utilizing environmental tools to encourage reading habits.

\section{Conclusions}

The level of reading comprehension of grade VII students of SMP Negeri 06 Rejang Lebong is still low. This can be seen from the results of the ability to read comprehension tests that still fall into the criteria of lack. Of the three aspects that become aspects of the assessment get an overall average value of 25 out of a maximum value of 100 , which consists of understanding aspects of written texts with an average value of 9 out of a maximum value of 40. Aspects of developing and interpreting meanings with an average value of 9 from the maximum value of 36 and finally aspects use meaning contextually with a value of 7 from the maximum value of 24 . All three 
aspects fall into the under criteria.

From the observation results, it is known that students still do not understand the literal and non-literal meaning well. Students still have difficulty explaining the contents of the text they are reading. In fact, understanding texts literally is a basic skill in reading comprehension. The cause of students' lack of understanding of the text of reading material is the lack of students' reading hobbies in reading books, students are more interested in reading on social media, reading messages through message sharing applications, which as we know, the language used is non-formal language. The next cause is reading that is still lacking in discipline.

Reading activities at school are only done when teaching and learning activities. His free time at school is spent going to the canteen and playing with friends. Reading activities in the library are very rarely done, reading in the library is when there are learning activities carried out in the library. The next cause is influenced by difficulty in understanding reading and reading fluency of students who are still lacking. Students still have difficulty understanding the reading text and are still not reading fluently.

From the results of this study, it is hoped that Indonesian language teachers' pay attention to students' reading abilities and encourage and enhance students' reading interest. The teacher must familiarize students with reading the text before entering core activities or observations. In addition, students are given the task to read novels, poems, story books, and others. The teacher also has to provide a lot of knowledge about reading comprehension, both theory and practice so that students are more able to master and understand. Then, for principals, it is expected to pay more attention to teaching and learning activities in schools and supervise students' reading activities in the library, so that the library functions as a safe and comfortable place to read for students. Flag ceremonies hold announcements and give gifts to students who are diligent in visiting the library.

\section{Acknowledgments}

We would like to express our special thanks and gratitude to Rector University of Bengkulu and Headmaster of SMP Negeri 06 Rejang Lebong who gave us the support to do this wonderful project. This project was funded independent. Secondly, we would also like to thank our friends in Faculty of Education Universitas Bengkulu who helped us a lot in finalizing this project within the limited time frame.

\section{REFERENCES}

[1] Afflerbach, P. (2010). Essential Reading on Assessment.
USA: International Reading Assosiation.

[2] Aisyah. (2016). Problematika Pemahaman Teks Bacaan pada Pelajaran Bahasa Indonesia Siswa Kelas IV MiIanatusshibyan Semarang Tahun Ajaran 2015/2016. Semarang: Universitas Islam Negeri Walisongo Semarang Fakultas Ilmu Tarbiyah dan Keguruan.

[3] Chair, C. S. (2002). Reading for Understanding. Santa Monica: RAND.

[4] Grabe, W. \& Stoller, F. L. (2002). Teaching and Researching Reading. New York: Routledge Taylor and Francis Group.

[5] Gusnetti, G., Zaim, M., Ramadhan, S., \& Agustina, A. (2019). Pengaruh Teknik Membaca SQ3R terhadap Membaca Pemahaman Mahasiswa FKIP Universitas Bung Hatta Padang. Ta'dib, 21(2), 121. Doi: 10.31958/Jt.V21i2. 1231

[6] Hermanudin, Suhartono, Suryadi, \& Noermanzah. (2019). Improvement of Reading Comprehension Ability by Using Core Models of Class VII Students of SMP Negeri 10 Bengkulu Tengah. International Journal of Scientific and Technology Research, 8(12), 647.

[7] Karto, Suhartono, Susetyo, Noermanzah, Maisarah, I. (2019). The Differences Ability in Writing Descriptive Texts by Using Chain Writing and Conventional Methods. International Journal of Scientific and Technology Research, 8(10).

[8] Khotimah, (2016). Analisis Kemampuan Membaca Pemahaman Berdasarkan Taksonomi Barret pada Siswa Kelas IV SD Negeri Gugus Dwija Harapan Kecamatan Mijen. Semarang: Universitas Negeri Semarang Fakultas Pendidikan Jurusan Pendidikan Sekolah Dasar.

[9] Kusmiarti, R., Yuniati, I., Noermanzah. (2020). Improving Student Communication Skills in Learning Indonesian Language through Collaborative Learning. International Journal of Scientific and Technology Research, 9(1). 207.

[10] Mawaria, M. (2019). Implementasi Metode SQ3R dalam Upaya Peningkatan Kemampuan Membaca Pemahaman pada Mata Pelajaran Bahasa Indonesia Siswa SDN 135 Rejang Lebong. AR-RIAYAH: Jurnal Pendidikan Dasar, 2(2), 177. doi: 10.29240/jpd.v2i2.663

[11] Minister of Education. (2013). Permendikbud Nomor 68 Tahun 2013 tentang KD dan Struktur Kurikulum SMP/MI. Jakarta: Menteri Pendidikan dan Kebudayaan Republik Indonesia.

[12] Mualimah, E. N., \& Usmaedi, U. (2018). Pengaruh Kebiasaan Membaca terhadap Prestasi Belajar Bahasa Indonesia Siswa Kelas V SDN Kubanglaban. Jurnal Pendidikan Sekolah Dasar, 4(1), 43. doi: 10.30870/jpsd.v4 i1.2459

[13] Novelti., Kristiawan, M., Erpidawati. (2019). Development of the Descriptive Writing Learning Model using the Audio Visual Media. International Journal of Recent Technology and Engineering, Volume-8 Issue-3, September 2019.

[14] Nurhadi. (2005). Bagaimana Meningkatkan Kemampuan Membaca: Suatu Teknik Memahami Literatur yang Efesien. Bandung: Sinar Baru Algensindo.

[15] Rahim, F. (2008). Pengajaran Membaca di Sekolah Dasar. 
Jakarta: Bumi Aksara.

[16] Santosa, A. (2019). Pengaruh Pola Asuh Orang Tua dan Sikap Bahasa terhadap Kemampuan Membaca Pemahaman. Jurnal Pendidikan Bahasa Indonesia, 6(2), 91. doi: 10.306 59/j.6.2.91-103.

[17] Suyana, N. (2019). Meningkatkan Kemampuan Membaca Pemahaman melalui Metode Preview, Question, Read, State, dan Test (PQRST). JIPIS, 28(2), 18-24. doi: 10.335 92/jipis.v28i2.308

[18] Syafryadin, Wardhana, D.E.C., Apriani, E., Noermanzah. (2020). Maxim Variation, Conventional and Particularized Implicature on Students' Conversation. International Journal of Scientific and Technology Research, 9(2).

[19] Tarigan, H. G. 2008. Membaca sebagai Suatu Keterampilan Berbahasa. Bandung: Angkasa.

[20] Thama, A. D. (2014). Kemampuan Membaca Pemahaman Siswa Kelas VII SMP Negeri 01 Kerkap Berdasarkan Taksonomi Barret. Bengkulu: Universitas Bengkulu, Fakultas Keguruan dan Pendidikan Bahasa dan Sastra Indonesia.

[21] Yunus, M. D., Yaacob, N., \& Suliman, A. (2020). The Use of Electronic Frog VLE in Assisting Reading Comprehension Activities. Universal Journal of Educational Research 8(3), 879. DOI: 10.13189/ujer.2020. 080319

[22] Yunus, M. Y., \& Machmury, A. (2019). Analisis Korelasi antara Kebiasaan Membaca dan Kemampuan Membaca Pemahaman pada Siswa Kelas IX SMP Kemala Bayangkari Makassar. Pepatudzu: Media Pendidikan dan Sosial Kemasyarakatan, 15(1), 14. doi: 10.35329/fkip.v15i1.311. 